\title{
PERAN DINAS KESEHATAN DALAM PENANGGULANGAN HUMAN IMMUNODEFICIENCY VIRUS -ACQUIRED IMMUNO DEFICIENCY SYNDROME (HIV-AIDS) SESUAI PERATURAN DAERAH NOMOR 2 TAHUN 2013 (Studi Di Kabupaten Kebumen)
}

\author{
Triyo Rachmadi \\ Magister IImu Hukum Fakultas Hukum Universitas Jenderal Soedirman
}

\begin{abstract}
Efforts to control HIV-AIDS is a program of technical effort in order to control the spread of HIV-AIDS in the health sector. The role of the District Health Office Kebumen responsible for organizing health service very necessary. This study aims to determine the role of law in the regulation of the subject area is to comply with its obligations and driving as well as the constraints faced in the prevention of HIV-AIDS in Kebumen. This study uses a socio-juridical approach to the primary data source and secondary data. Collecting data with the study of documents, observations and interviews with informants. Location of research in the District, Health, Office, Kebumen. The results showed that of the six indicators of HIVAIDS organizing appropriate Local Regulations Number 2 of years 2013 has not been implemented. These six indicators are policies and strategies, prevention of HIV-AIDS, HIV-AIDS treatment, rehabilitation of HIV-AIDS, Local Government responsibilities and obligations, prohibitions, administrative sanctions. Thus the role of the District Health Office Kebumen in HIV-AIDS accordance Local Regulation Number 2 of Years 2013 is still lacking.
\end{abstract}

Keywords: District Health Office, HIV-AIDS, Local Regulations

\begin{abstract}
Abstrak
Upaya penanggulangan HIV-AIDS merupakan suatu program upaya teknis dalam rangka mengendalikan penyebaran HIV-AIDS di sektor kesehatan. Program ini sangat didukung oleh Pemerintah Kabupaten Kebumen dengan menerbitkan Peraturan Daerah Nomor 2 tahun 2013 tentang Penanggulangan HIV-AIDS. Kewajiban Pemerintah Daerah adalah menyediakan sarana pelayanan kesehatan dalam melayani pengobatan bagi Orang Dengan HIV-AIDS (ODHA). Peran Dinas Kesehatan Kabupaten Kebumen yang bertanggung jawab dalam penyelenggaraan pelayananan kesehatan sangat diperlukan. Penelitian ini bertujuan mengetahui peran dari subjek hukum dalam Peraturan Daerah ini untuk mematuhi kewajiban-kewajibannya dan pendorong serta kendala-kendala yang dihadapi dalam penanggulangan HIV-AIDS di Kabupaten Kebumen. Penelitian ini menggunakan metode pendekatan yuridis sosiologis dengan sumber data primer dan data sekunder. Pengumpulan data dengan studi dokumen, observasi dan wawancara dengan informan. Lokasi penelitian di Dinas Kesehatan Kabupaten Kebumen. Hasil penelitian menunjukkan bahwa dari enam indikator penyelenggaran penanggulangan HIV-AIDS sesuai Peraturan Daerah Nomor 2 Tahun 2013 belum dilaksanakan. Keenam indikator tersebut adalah kebijakan dan strategi, pencegahan HIV-AIDS, penanganan HIV-AIDS, rehabilitasi HIVAIDS, tanggung jawab Pemerintah Daerah dan kewajiban, larangan, sanksi administratif. Dengan demikian peran Dinas Kesehatan Kabupaten Kebumen dalam penanggulangan HIV-AIDS sesuai Peraturan Daerah Nomor 2 tahun 2013 masih kurang.
\end{abstract}

Kata Kunci: Dinas Kesehatan, HIV-AIDS, Peraturan Daerah

\section{Pendahuluan}

Di Kabupaten Kebumen sendiri kasus HIVAIDS tampak sebagai fenomena gunung es yang secara kumulatif sejak tahun 2003 sampai dengan Desember 2013 ditemukan kasus baru sejumlah 279 kasus. Fenomena gunung es dalam kasus penyakit HIV-AIDS ini bermakna bahwa orang yang terinfeksi HIV-AIDS yang diketahui dan dilaporkan hanyalah bagian kecil dari jumlah yang sebenarnya sementara bagian jumlah yang lebih besar tersembunyi dan tidak diketahui jumlahnya. Kasus tertinggi terjadi pada tahun 2013 yaitu 92 kasus. Data kasus HIV-AIDS di Kabupaten Kebumen dari tahun ke tahun mengalami 
60 Jurnal Idea Hukum

Vol. 1 No. 1 Edisi Maret 2015

Magister Hukum Fakultas Hukum Universitas Jenderal Soedirman

kecenderungan peningkatan kasus secara signifikan.

Di Kabupaten Kebumen program penanggulangan HIV-AIDS sangat didukung oleh Pemerintah Kabupaten Kebumen dengan menerbitkan Peraturan Daerah Nomor 2 tahun 2013 tentang Penanggulangan HIV-AIDS. Kewajiban Pemerintah Daerah adalah menyediakan sarana pelayanan kesehatan seperti Rumah Sakit dan Puskesmas dalam melayani pengobatan bagi ODHA. Peran Dinas Kesehatan Kabupaten Kebumen yang membawahi seluruh Unit Pelaksana Teknis (UPT) Puskesmas di setiap kecamatan dalam upaya penanggulangan HIV-AIDS belum diatur secara tegas dalam peraturan perundangundangan terutama Peraturan Daerah Kabupaten Kebumen Nomor 2 tahun 2013. Berdasarkan Keputusan Menteri Kesehatan RI (Kepmenkes RI) Nomor 267 Tahun 2008 tentang Pedoman Teknis Pengorganisasian Dinas Kesehatan Daerah yang mengatur bahwa Dinas Kesehatan Kabupaten atau Kota bertanggung jawab dalam penyelenggaraan upaya pelayanan kesehatan di tiap wilayah kabupaten atau kota termasuk dalam penyelenggaraan pencegahan dan penanggulangan penyakit menular khususnya HIVAIDS. Program pelayanan kesehatan pada penanggulangan HIV-AIDS yang telah diatur oleh Peraturan Daerah Nomor 2 tahun 2013 yaitu pencegahan, penanganan dan rehabilitasi HIVAIDS yang meliputi pelayanan Klinik Infeksi Menular Seksual (IMS), Voluntary Counceling and Testing (VCT), Provider-Initiated Testing and Counseling (PITC), Care Support and Treatment (CST) dan Prevention Mother to Child Transmision (PMTCT) belum dapat dilaksanakan secara optimal. Peran Dinas Kesehatan selain berfungsi melaksanakan pembinaan, pengawasan, merumuskan kebijakan dan pengembangan sumber daya kesehatan juga diperlukan dalam penanggulangan penyakit HIV - AIDS.

\section{Perumusan Masalah}

Berdasarkan latar belakang masalah tersebut di atas, maka dapat dirumuskan permasalahan sebagai berikut: Pertama, bagaimana peran Dinas Kesehatan Kabupaten Kebumen dalam penanggulangan Human Immunodeficien- cy Virus-Acquired Immuno Deficiency Syndrome (HIV-AIDS) sesuai Peraturan Daerah Nomor 2 tahun 2013; Kedua, faktor-faktor apa yang mendukung dan menghambat peran Dinas Kesehatan Kabupaten Kebumen dalam penanggulangan HIV-AIDS sesuai Peraturan Daerah Nomor 2 Tahun 2013.

\section{Metode Penelitian}

Penelitian ini menggunakan metode kualitatif dengan pendekatan empiris atau yuridis sosiologis. Spesifikasi penelitian ini merupakan penelitian hukum empiris kualitatif yang lebih memfokuskan pada spesifikasi penelitian deskriptif. Terdapat tiga variabel yang diteliti yaitu: (1) Variabel Independen (Variabel Bebas) merupakan variabel yang menjadi sebab timbulnya atau berubahnya variabel dependen (terikat) yaitu $\mathrm{Pe}$ raturan Daerah Nomor 2 Tahun 2013; (2) Variabel Dependen (Variabel terikat) merupakan variabel yang dipengaruhi atau menjadi akibat karena adanya variabel independent (bebas). Dalam penelitian ini yaitu Dinas Kesehatan; (3) Variabel Pengganggu merupakan variabel yang dikendalikan atau dibuat konstan sehingga tidak akan mempengaruhi variabel utama yang akan diteliti. Dalam penelitian ini yaitu kehidupan keluarga dan nilai-nilai dalam lingkungan masyarakat.

Informan ditentukan dengan cara atau metode "Purposive Sampling". Untuk pemilihan berikutnya digunakan metode Snow Ball Sampling. Sumber data dapat berupa sumber data primer dan sumber data sekunder. Metode uji mutu data dilakukan dengan cara Triangulasi. Metode Triangulasi yang digunakan adalah jenis Triangulasi Sumber, Triangulasi Metode dan Triangulasi Waktu. Metode analisis data dilakukan dengan kualitatif, Reduksi data dan Display data.

\section{Pembahasan}

Peran Dinas Kesehatan Kabupaten Kebumen dalam penanggulangan Human Immunodeficiency Virus-Acquired Immuno Deficiency Syndrome (HIV-AIDS) sesuai Peraturan Daerah Nomor 2 tahun 2013

Data primer diperoleh dengan wawancara dan observasi langsung dengan para informan 
yang meliputi pejabat eselon di Dinas Kesehatan Kabupaten Kebumen diantaranya Kepala Dinas Kesehatan Kabupaten Kebumen, Sekretaris Dinas Kesehatan Kabupaten Kebumen, Kepala Bidang Pelayanan Kesehatan (Yankes), Kepala Bidang Pengendalian Masalah Kesehatan (PMK), Kepala Bidang Pengembangan Sumber Daya Manusia Kesehatan (PSDMK), Kepala Bidang Jaminan Sarana Kesehatan (JSK), Kepala Seksi Kesehatan Dasar Rujukan dan Khusus, Kepala Seksi Kesehatan lbu dan Anak (KIA), Kepala Seksi Gizi, Kepala Seksi Pengendalian Pemberantasan Penyakit (P3), Kepala Seksi Wabah dan Bencana (WB), Kepala Seksi Kesehatan Lingkungan (KL), Kepala Seksi Jaminan Kesehatan, Kepala Seksi Sarana dan Peralatan Kesehatan, Kepala Seksi Kefarmasian, Kepala Seksi Promosi Kesehatan, Kepala Seksi Registrasi dan Akreditasi, Kepala Seksi Perencanaan, Kepala Seksi Informasi Penelitian Pengembangan Kesehatan (Infolitbangkes), Koordinator Program Penyakit HIV-AIDS dan Manajer Kasus di Klinik VCT. Kemudian dari masyarakat umum yaitu tokoh masyarakat di desa yang berbeda yaitu $\mathrm{Ba}-$ pak Abu Salim, Bapak Saeful Bahri, Bapak Mustakim, Bapak Rodiman dan Bapak Parjono sedangkan dari pasien atau ODHA yaitu penderita HIV-AIDS yang berkunjung ke Klinik VCT Rumah Sakit Umum Daerah Kebumen dan UP3 terdiri dari Bapak S, Sdr. T dan Sdr. AA.

Dinas Kesehatan Kabupaten telah melaksanakan kebijakan dan strateginya dengan lebih banyak melakukan kegiatan penanggulangan HIV-AIDS baik secara program maupun dengan lintas sektoral. Penanggulangan HIV-AIDS di Dinas Kesehatan Kabupaten Kebumen tidak dilakukan oleh semua Bidang maupun Seksi tetapi lebih banyak ditangani oleh Seksi Pengendalian Pemberantasan Penyakit (P3) di Bidang Penanggulangan Masalah Kesehatan (PMK). Bidang atau seksi yang membantu diantaranya adalah empat Bidang dan enam Seksi.

Dinas Kesehatan Kabupaten Kebumen selalu bekerjasama dengan Klinik VCT di RSUD Kebumen baik dalam kegiatan maupun dalam sarana pelayanan pencegahan HIV-AIDS. Kegiatan di Dinas Kesehatan Kabupaten Kebumen lebih banyak dilaksanakan pada kegiatan pro- mosi KIE, penyuluhan ke masyarakat maupun penjangkauan ke titik tempat kelompok resiko tinggi, penyediaan layanan VCT, IMS, PITC dan pemulasaran jenazah, tetapi belum mengarah kepada pengawasan dan pengontrolan darah serta produk darah yang bebas HIV. Kegiatan pencegahan HIV-AIDS di Dinas Kesehatan Kabupaten Kebumen masih ditangani 9 (sembilan) Bidang dan Seksi yaitu empat bidang dan lima seksi.

Dinas Kesehatan Kabupaten Kebumen hanya dapat melaksanakan langkah-langkah penanganan HIV-AIDS melalui upaya dukungan pelayanan IMS, VCT. Pengobatan ARV masih bekerjasama dengan Klinik VCT RSUD Kebumen dan PITC. Langkah-langkah tersebut dilaksanakan melalui dua Bidang dan dua Seksi saja. Sedangkan upaya dukungan pelayanan CST dan PMTCT lebih banyak dilakukan oleh Klinik VCT di RSUD Kebumen. Upaya peningkatan kualitas dan kuantitas tenaga kesehatan HIV-AIDS belum dilakukan sepenuhnya oleh Dinas Kesehatan Kabupaten Kebumen. Pelatihan tenaga kesehatan baru dilakukan pada pelatihan PITC dan pemulasaran jenazah. Hal ini berkaitan dengan anggaran yang terbatas. Pendampingan bagi kelompok rawan ODHA belum dapat dilakukan secara mandiri tetapi masih dibantu oleh Manajer Kasus dari RSUD Kebumen.

Dinas Kesehatan Kabupaten Kebumen belum dapat melaksanakan kegiatan rehabilitasi HIV-AIDS secara mandiri tetapi masih bekerjasama dengan LSM, KDS dan dinas lain yang terkait. Dari koordinasi dan kerjasama tersebut belum sepenuhnya dapat dilaksanakan dikarenakan adanya peraturan dan prinsip dalam penanggulangan HIV-AIDS yaitu no death, no new infection dan no discrimination melalui upaya kerahasiaan penderita HIV-AIDS.

Dinas Kesehatan Kabupaten Kebumen telah banyak melaksanakan tanggung jawabnya sebagai institusi sarana pelayanan kesehatan kepada masyarakat. Dari hasil wawancara peneliti dengan responden, ada 10 (sepuluh) Bidang dan Seksi yang bertanggung jawab dalam penanggulangan HIV-AIDS di Kabupaten Kebumen sesuai dengan tugas pokok serta fungsinya masing-masing. 
Empat bidang dan seksi yang terkait langsung dengan penanggulangan HIV-AIDS di Dinas Kesehatan Kabupaten Kebumen berpendapat kewajiban dan larangan telah berjalan dengan baik dengan adanya Klinik VCT. Sanksi belum dapat diberikan atau diterapkan dikarenakan belum ditemukannya permasalahan pada sarana pelayanan kesehatan dan Dinas Kesehatan Kabupaten Kebumen selalu memantau pelayanan di Klinik VCT dan Puskesmas. Tenaga kesehatan di Dinas Kesehatan Kabupaten Kebumen dan Puskesmas masih banyak yang belum mengetahui isi dari Peraturan Daerah Nomor 2 tahun 2013 tentang Penanggulangan HIVAIDS.

Beberapa tokoh masyarakat memberikan informasi tentang bentuk-bentuk kegiatan penyuluhan kesehatan yang diberikan oleh tenaga kesehatan Puskesmas maupun Dinas Kesehatan Kabupaten Kebumen yaitu penyuluhan ceramah biasa, pemutaran film dan pembentukan WPA. Tokoh masyarakat menganggap semua tenaga kesehatan baik dari Puskesmas maupun dari Rumah Sakit yang melaksanakan kegiatan penanggulangan HIV-AIDS di desanya adalah petugas dari Dinas Kesehatan Kabupaten Kebumen. Dari pendapat tokoh masyarakat tersebut, masih ada anggapan negatif dan stigma dari masyarakat kepada orang yang telah terinfeksi HIV-AIDS.

ODHA telah mendapatkan pelayanan kesehatan yang di Puskesmas dan tenaga kesehatan di wilayah domisili tempat tinggalnya. Penanganan pengobatan HIV-AIDS masih dilaksanakan di Klinik VCT RSUD Kebumen begitu pula dengan pemantauan kadar CD-4 masih dilaksanakan di laboratorium swasta. Upaya rehabilitasi belum dilaksanakan oleh dinas terkait tetapi masih dilakukan oleh KDS dan RSUD Kebumen.

Data sekunder yang digunakan adalah $\mathrm{Pe}$ raturan Daerah Kabupaten Kebumen Nomor 2 Tahun 2013 tentang Penanggulangan HIV-AIDS. Keputusan Menteri Kesehatan Republik Indonesia (Kepmenkes RI) Nomor 267 Tahun 2008 tentang Pedoman Teknis Pengorganisasian Dinas Kesehatan Daerah, Profil Dinas Kesehatan Kabupaten Kebumen, Kebijakan Program Nasional Penanggulangan IMS, HIV dan AIDS.
Berdasarkan hasil observasi dan wawancara, peran Dinas Kesehatan Kabupaten Kebumen dalam penanggulangan HIV-AIDS belum sepenuhnya dilaksanakan. Dari keenam indikator penyelenggaraan penanggulangan HIV-AIDS sesuai Peraturan Daerah Nomor 2 Tahun 2013 yaitu kebijakan dan strategi, pencegahan, penanganan, rehabilitasi, tanggung jawab, kewajiban, larangan dan sanksi administrasi hanya empat yang berperan, yaitu kebijakan dan strategi, pencegahan, tanggung jawab, kewajiban, larangan dan sanksi administrasi itupun belum sepenuhnya dilaksanakan. Diperlukan upaya pengembangan yang lebih optimal pada penyelenggaraan penanggulangan HIV-AIDS di Dinas Kesehatan Kabupaten Kebumen. Dengan banyaknya tanggung jawab yang belum dilaksanakan maka tujuan dari Peraturan Daerah Nomor 2 Tahun 2013 tentang Penanggulangan HIV-AIDS menjadi belum terwujud.

Ada enam indikator peran Dinas Kesehatan Kabupaten Kebumen dalam penanggulangan HIV-AIDS sesuai Peraturan Daerah Nomor 2 Tahun 2013 tentang Penanggulangan HIV-AIDS yaitu: (1) Kebijakan dan Strategi Penyelenggaraan; (2) Pencegahan HIV-AIDS; (3) Penanganan HIV-AIDS; (4) Rehabilitasi HIV-AIDS; (5) Tanggung jawab Pemerintah Daerah; (6) Kewajiban, larangan dan sanksi administratif.

\section{Faktor-Faktor Yang Menghambat Peran Dinas Kesehatan Kabupaten Kebumen Dalam Pe- nanggulangan HIV-AIDS Sesuai Dengan Pera- turan Daerah Nomor 2 Tahun 2013}

Adapun faktor-faktor penyebab tidak bekerjanya hukum sehingga menjadi kendala pada peran Dinas Kesehatan Kabupaten Kebumen dalam penanggulangan HIV-AIDS sesuai Peraturan Daerah Nomor 2 Tahun 2013 adalah:

Pertama, Faktor hukumnya, yang dalam hal ini adalah Peraturan Daerah Nomor 2 tahun 2013 tentang Penanggulangan HIV-AIDS. Faktor tidak bekerjanya hukum dari faktor hukumnya adalah ketidaksesuaian antara Peraturan Daerah Nomor 2 Tahun 2013 tentang Penanggulangan HIV-AIDS dengan Kepmenkes RI Nomor 267 Tahun 2008 tentang Pedoman Teknis Pengorganisasian Dinas Kesehatan Daerah dalam hal 
tugas, tanggung jawab dan kewajiban atau peran dari Dinas Kesehatan Kabupaten Kebumen pada penanggulangan HIV-AIDS. Sedangkan ketentuan pidana pada ODHA yang tidak menjalankan pengobatan tidak sinkron dengan Undang-Undang Nomor 36 tahun 2009 tentang Kesehatan dan Undang-Undang RI Nomor 39 Tahun 1999 tentang Hak Asasi Manusia. Ketidaksesuaian peraturan ini bila dihubungkan dengan ajaran Soerjono Soekanto mengenai faktor-faktor yang mempengaruhi penegakan hukum termasuk pada faktor ke satu yaitu faktor hukumnya.

Kedua, Faktor penegak hukum. Tenaga kesehatan yang bekerja belum memiliki pengetahuan yang memadai dalam menghadapi ODHA. Tenaga kesehatan yang ada di Kabupaten Kebumen belum mendapatkan pendidikan dan pelatihan sehingga masih beranggapan negatif yang dapat mengakibatkan stigma dan kemungkinan melakukan diskriminasi terhadap ODHA. Masih adanya tenaga kesehatan yang khawatir dengan penularan terhadap dirinya dan sebagian besar tenaga kesehatan belum mengetahui secara lengkap Peraturan Daerah Nomor 2 tahun 2013 tentang Penanggulangan HIV-AIDS menyebabkan faktor penegak hukum menjadi terhambat.

Belum ditemukan laporan badan atau lembaga dan penyedia pelayanan kesehatan yang melanggar ketentuan dari Peraturan Daerah Nomor 2 Tahun 2013 ini. Bupati sebagai pelaksana dalam memberikan pembinaan dan pengawasan terhadap Dinas Kesehatan Kabupaten Kebumen juga belum menerapkan sanksi tetapi menerapkan komunikasi dan koordinasi apabila ditemukan adanya pelanggaran dalam penanggulangan HIV-AIDS. Dalam keanggotaan KPAD, Dinas Kesehatan Kabupaten Kebumen masuk menjadi anggota dalam Pokja Surveilans dan Pokja Promosi Kesehatan. Belum optimalnya tim yang bertugas melakukan pembinaan, pengawasan dan pemberian sanksi administratif dalam penanggulangan HIV-AIDS baik di Dinas Kesehatan Kabupaten Kebumen maupun di Pemerintah Daerah dan KPAD Kebumen serta perilaku yang negatif dari tenaga kesehatan tehadap ODHA.

\section{Sarana dan fasilitas yang mendukung penegakan hukum}

Belum adanya sarana dan fasilitas pelayanan kesehatan yang mendukung penanggulangan HIV-AIDS. Tanpa adanya sarana maka tidak mungkin penegakan hukum akan berjalan sesuai aturan sehingga perlindungan terhadap masyarakat dan kelompok beresiko tinggi dari penularan HIV-AIDS tidak terwujud.

\section{Faktor masyarakat dan kebudayaan.}

Masyarakat di Kabupaten Kebumen sendiri masih memiliki stigma buruk dan kecenderungan melakukan diskriminasi terhadap ODHA yang menjalani pengobatan di sarana pelayanan kesehatan. Selain itu adanya budaya dari masyarakat Jawa bahwa belum akan berobat bila kondisi penyakit belum parah sehingga pada umumnya yang berobat sudah dalam kondisi yang berat.

\section{Penutup \\ Simpulan}

Berdasarkan hasil penelitian ini, maka dapat disimpulkan: Pertama, Peran Dinas Kesehatan Kabupaten Kebumen dalam penanggulangan HIV-AIDS sesuai Peraturan Daerah Nomor 2 tahun 2013 masih kurang dikarenakan dari enam indikator penanggulangan HIV-AIDS, baru empat indikator yang telah dilaksanakan yaitu indikator kebijakan dan strategi, pencegahan, tanggung jawab Pemerintah Daerah dan kewajiban, larangan, sanksi administratif. Indikator yang belum dilaksanakan adalah penanganan dan rehabilitasi HIV-AIDS sehingga tujuan dari bekerjanya hukum Peraturan Daerah ini belum tercapai.

Kedua, terdapat berbagai macam kendala yang dihadapi pada peran Dinas Kesehatan Kabupaten Kebumen dalam penanggulangan HIVAIDS.

\section{Saran}

Adapun saran dari peneliti adalah Mengoptimal-kan semua Bidang, Seksi-Seksi, tim pembinaan dan pengawasan dalam penanggulangan HIV-AIDS baik di Dinas Kesehatan Kabupaten Kebumen maupun di Pemerintah Daerah serta KPAD Kebumen sehingga penyimpangan atau pelanggaran dapat diminimalisir. Dinas Kesehatan Kabupaten Kebumen segera me- 
64 Jurnal Idea Hukum

Vol. 1 No. 1 Edisi Maret 2015

Magister Hukum Fakultas Hukum Universitas Jenderal Soedirman

lengkapi diri dengan sarana dan fasilitas dalam pencegahan, penanganan maupun rehabilitasi HIV-AIDS sehingga dapat berjalan bersama-sama dengan Klinik VCT, IMS, CST, PMTCT di Rumah Sakit Umum Daerah Kebumen. Dinas Kesehatan Kabupaten Kebumen mengutamakan kehati-hatian dengan memperhatikan nilai-nilai, norma dan budaya di masyarakat. 